\title{
Removing the blindfold on medicines pricing
}

\section{Citation}

Moon, Suerie. 2018. "Removing the Blindfold on Medicines Pricing." BMJ (February 26): k840. doi:10.1136/bmj.k840.

\section{Published Version}

10.1136/bmj.k840

\section{Permanent link}

http://nrs.harvard.edu/urn-3:HUL.InstRepos:37263453

\section{Terms of Use}

This article was downloaded from Harvard University's DASH repository, and is made available under the terms and conditions applicable to Other Posted Material, as set forth at http:// nrs.harvard.edu/urn-3:HUL.InstRepos:dash.current.terms-of-use\#LAA

\section{Share Your Story}

The Harvard community has made this article openly available.

Please share how this access benefits you. Submit a story.

\section{Accessibility}




\title{
Removing the blindfold on medicines pricing
}

\author{
Increased transparency would enable more evidence based policy making
}

\author{
Suerie Moon director of research \\ Global Health Centre, Graduate Institute of International and Development Studies, Geneva, Switzerland
}

Tisagenlecleucel (Kymriah), one of several promising chimeric antigen receptor $\mathrm{T}$ cell (CAR-T) therapies, is the first gene therapy to get US approval. Novartis announced in September 2017 that the leukaemia treatment would cost $\$ 475000$ (£340 000 ; $€ 390000$ )—double the median house price in the US, or 60 years of mortgage payments for the average family.

\section{What we don't know}

Medicines pricing debates have run the same, stale course for decades: on one side is the need to ensure access to lifesaving medicines; on the other, the importance of rewarding risky, costly research and development. Unsurprisingly, industry's estimates of the average cost of developing new medicines-albeit hotly contested-have ballooned every few years. ${ }^{12}$ More surprisingly, society has been participating blindfolded in this debate.

What don't we know? The actual prices paid for medicines are increasingly hidden behind confidentiality agreements. ${ }^{3}$ In a "beggar thy neighbour" dynamic, every payer believes it is getting the best price but cannot verify this-and largely negotiates in the dark. Companies claim that transparency will lead to higher prices for poorer countries. But experience from the global HIV and vaccines markets, where prices have been quite transparent for years, show that substantial price differentials between higher and lower income countries can be sustained. ${ }^{45}$ Nor do prices always correspond to ability to pay. ${ }^{56}$ Sellers also threaten that disclosure will preclude discounts from the list price. But too little attention is given to whether list prices are justified to begin with.

Indeed, limited information on the value of a new medicine is available when prices are negotiated. New medicines have been used in a relatively small number of people; longer term, larger scale, quality data on safety, efficacy, and effect on quality of life or health systems may not yet exist. Even when they do, such data may not be publicly available: despite widespread requirements that clinical trial results be published, most are not. $^{7}$

\section{"Value based" pricing}

These information problems make it difficult for health technology assessment bodies such as the UK's National Institute for Health and Care Excellence (NICE) to gauge whether industry's increasing adoption of "value based pricing" in fact offers society a reasonable deal. A recent review of 68 cancer drugs approved by the European Medicines Agency from 2009 to 2013 found that only half offered any sizeable benefit, despite the high prices being paid. ${ }^{8}$ Even when the added therapeutic value of a medicine is well established, a value based price may not be affordable to health systems. Pricing hepatitis $\mathrm{C}$ drugs at the cost of liver transplantation, for example, has produced waiting lists and rationing among sick patients. ${ }^{9}$

Finally, data are scarce on who contributed financially, how much, and when to research and development. CAR-T technology was developed with over $\$ 200 \mathrm{~m}$ in US federal government grants. ${ }^{112}$ Tisagenlecleucel originated at the University of Pennsylvania, and was later licensed to Novartis. Because tisagenlecleucal received orphan drug designation in Europe and the US, Novartis may receive enhanced market exclusivity rights and tax breaks covering $50 \%$ of clinical development expenditure. ${ }^{13}$

Many other drugs share this trajectory-early academic research is government funded, a firm will acquire a promising technology and invest in further development, and governments provide additional incentives to reduce industry's costs. ${ }^{14}$ However, the absence of specific data on research and development contributions prevents informed debate on whether a drug price appropriately reflects this division of labour, financing, and risk; whether there is a fair public return on public investment; whether profit margins are reasonable; or how to improve policies and incentives for innovation.

\section{Removing the blindfold}

Fortunately, it is possible to remove the blindfold. Payers can refuse to sign price confidentiality agreements, which have become common only relatively recently. ${ }^{3}$ Several groups of European countries (BeneluxA (Belgium, Netherlands, Luxembourg, and Austria), Valletta (Malta, Cyprus, Greece, 
Italy, Spain, Portugal, Ireland, Romania, Slovenia, and Croatia), and Visegrad (the Czech Republic, Slovakia, Hungary, and Poland), covering $38 \%$ of the EU economy) have recently agreed to cooperate on medicines policies, including improving price transparency among collaborating countries. Governments can also mandate price disclosure. Regulatory agencies, courts, research funders, and journal editors can more proactively enforce requirements to publish the results of clinical trials. ${ }^{15}$ Legislative or judicial action could require disclosure of development costs, including contributions of public grants, tax breaks, or other incentives.

Increased transparency alone will not solve the problem of unaffordable drug prices, but it would enable more evidence based policy making. Calls for such transparency have been gathering momentum at local, national, and international levels. ${ }^{16}{ }^{17}$

Some have objected, perhaps fearing that further public scrutiny could decrease industry pricing power. And this may be true in the short term. But in the medium term, a better informed public debate on drug pricing would produce a more sustainable pharmaceutical business model. An industry with such profound implications for the public interest should not be shrouded in so much secrecy.

Competing interests: I have read and understood BMJ policy on declaration of interests and have no relevant interests to declare.

Provenance and peer review: Commissioned; not externally peer reviewed.

Morgan S, Grootendorst P, Lexchin J, Cunningham C, Greyson D. The cost of drug development: a systematic review. Health Policy 2011;100:4-17. 10.1016/j.healthpol.2010.12.002 21256615
2 Prasad V, Mailankody S. Research and development spending to bring a single cancer drug to market and revenues after approval. JAMA Intern Med 2017:177:1569-75. 10.1001/jamainternmed.2017.3601 28892524

3 Morgan SG, Vogler S, Wagner AK. Payers' experiences with confidential pharmaceutical price discounts: a survey of public and statutory health systems in North America, Europe, and Australasia. Health Policy 2017;121:354-62.

10.1016/j.healthpol.2017.02.002 28238340

4 Waning B, Kaplan W, Fox MP, etal . Temporal trends in generic and brand prices of antiretroviral medicines procured with donor funds in developing countries. J Gene Med 2010;7:159-7510.1057/jgm.2010.6.

5 World Health Organization. Global Vaccine Action Plan (GVAP) secretariat annual report 2017. WHO, 2017. http://www.who.int/immunization/global_vaccine_action_plan/web gvap_secretariat_report_2017.pdf?ua=1

6 lyengar S, Tay-Teo K, Vogler S, etal. Prices, costs, and affordability of new medicines for hepatitis C in 30 countries: an economic analysis. PLoS Med 2016;13:e1002032. 10.1371/journal.pmed.1002032 27243629

7 Anderson ML, Chiswell K, Peterson ED, Tasneem A, Topping J, Califf RM. Compliance with results reporting at ClinicalTrials.gov. N Engl J Med 2015;372:1031-9. 10.1056/NEJMsa1409364.

8 Davis C, Naci H, Gurpinar E, Poplavska E, Pinto A, Aggarwal A. Availability of evidence of benefits on overall survival and quality of life of cancer drugs approved by European Medicines Agency: retrospective cohort study of drug approvals 2009-13. BMJ 2017;359:j4530. 10.1136/bmj.j4530 28978555

9 Canary LA, Klevens RM, Holmberg SD. Limited access to new hepatitis $C$ virus treatment under state Medicaid programs. Ann Intern Med 2015;163:226-8. 10.7326/M15-0320 26121095

11 Kochenderfer JN, Wilson WH, Janik JE, etal . Eradication of B-lineage cells and regression of lymphoma in a patient treated with autologous $\mathrm{T}$ cells genetically engineered to recognize CD19. Blood 2010;116:4099-102. 10.1182/blood-2010-04-281931 20668228

12 Love J, Singhroy D. Federal funding to organizations for projects related to chimeric antigen receptors. Knowledge Ecology International 2017. https://www.keionline.org/23838

13 Kleutghen P, Mitchell D, Kesselheim AS, Najafzadeh M, Sarpatwari A. Drugs don't work if people can't afford them: the high price of tisagenlecleucel. Health Affairs Blog 2018. https://www.healthaffairs.org/do/10.1377/hblog20180205.292531/full/

14 Sampat BN, Lichtenberg FR. What are the respective roles of the public and private sectors in pharmaceutical innovation? Health Aff (Millwood) 2011;30:332-9. 10.1377/hlthaff.2009.0917 21289355

15 Bruckner T. Clinical trial transparency: a guide for policymakers. TranspariMed, 2017. http://www.transparency.org.uk/publications/clinical-trial-transparency/\#.WoGyf2duxXs

16 UN Secretary General's High Level Panel on Access to Medicines. Promoting innovation and access. http://www.unsgaccessmeds.org/\#homepage-1

17 Wirtz VJ, Hogerzeil HV, Gray AL, etal . Essential medicines for universal health coverage. Lancet 2017;389:403-76. 10.1016/S0140-6736(16)31599-9 27832874

Published by the BMJ Publishing Group Limited. For permission to use (where not already granted under a licence) please go to http://group.bmj.com/group/rights-licensing/ permissions 